Provided for non-commercial research and educational use only. Not for reproduction or distribution or commercial use.



This article was originally published in a journal published by Elsevier, and the attached copy is provided by Elsevier for the author's benefit and for the benefit of the author's institution, for non-commercial research and educational use including without limitation use in instruction at your institution, sending it to specific colleagues that you know, and providing a copy to your institution's administrator.

All other uses, reproduction and distribution, including without limitation commercial reprints, selling or licensing copies or access, or posting on open internet sites, your personal or institution's website or repository, are prohibited. For exceptions, permission may be sought for such use through Elsevier's permissions site at:

http://www.elsevier.com/locate/permissionusematerial 


\title{
Measuring $\mathrm{Ca}^{2+}$-signalling at fertilization in the sea urchin Psammechinus miliaris: Alterations of this $\mathrm{Ca}^{2+}$-signal by copper and 2,4,6-tribromophenol
}

\author{
Sabine Schäfer ${ }^{\mathrm{a}}$, Ulf Bickmeyer ${ }^{\mathrm{b}}$, Angela Koehler ${ }^{\mathrm{a}, *}$ \\ a Alfred Wegener Institute for Polar and Marine Research in the Helmholtz Association, Am Handelshafen 12, 27570 Bremerhaven, Germany \\ b Biologische Anstalt Helgoland, Alfred Wegener Institute for Polar and Marine Research in the Helmholtz Association, Kurpromenade 201, 27483 Helgoland, Germany
}

\section{A R T I C L E I N F O}

\section{Article history:}

Received 28 January 2009

Received in revised form 8 May 2009

Accepted 10 May 2009

Available online 18 May 2009

\section{Keywords:}

Calcium signalling

Copper

Fertilization

MK571

Sea urchin

2,4,6-tribromophenol

MRP

\begin{abstract}
A B S T R A C T
During fertilization, eggs undergo a temporary rise in the intracellular concentration of free $\mathrm{Ca}^{2+}$ ions. Using the membrane permeable acetoxymethylester of the fluorescent calcium indicator dye Fura-2, Fura- $2 \mathrm{AM}$, the $\mathrm{Ca}^{2+}$-signal at fertilization was not detectable in eggs of the sea urchin Psammechinus miliaris. However, after treatment of the eggs with Fura-2 AM in combination with MK571, an inhibitor for multidrug resistance associated proteins, clear $\mathrm{Ca}^{2+}$-signals at fertilization could be measured without microinjection of the dye. We used this methodology to detect possible alterations of $\mathrm{Ca}^{2+}$-signalling at fertilization by exposure of eggs to environmental pollutants. For this purpose, the heavy metal copper, the bromophenol 2,4,6tribromophenol, the organic compound bisphenol A and the polycyclic aromatic hydrocarbon phenanthrene were tested for their potential to inhibit fertilization success of $P$. miliaris. Copper and 2,4,6-tribromophenol showed a dose-dependent effect on fertilization rates of $P$. miliaris and significantly inhibited fertilization at $6.3 \mu \mathrm{M} \mathrm{Cu}{ }^{2+}$ and $1 \mu \mathrm{M} \mathrm{2,4,6-tribromphenol.} \mathrm{Bisphenol} \mathrm{A} \mathrm{significantly} \mathrm{inhibited} \mathrm{fertilization} \mathrm{success} \mathrm{at}$ $438 \mu \mathrm{M}$ while phenanthrene had no effect up to $56 \mu \mathrm{M}$. $6.3 \mu \mathrm{M}$ copper and $100 \mu \mathrm{M}$ 2,4,6-tribromophenol significantly increased the $\mathrm{Ca}^{2+}$-signal at fertilization. This alteration may contribute to the reduced fertilization rates of $P$. miliaris after exposure to copper and 2,4,6-tribromophenol.
\end{abstract}

(c) 2009 Elsevier Inc. All rights reserved.

\section{Introduction}

Free calcium ions are essential second messengers in cells from their origin at fertilization throughout their entire lifespan (Carafoli, 2002). Disruption of cellular $\mathrm{Ca}^{2+}$ homeostasis appears to mediate the toxicity of many chemicals (Nicotera et al., 1992). Sustained increase in intracellular $\mathrm{Ca}^{2+}$ can provoke cytotoxic mechanisms in various cells and tissues by activation of $\mathrm{Ca}^{2+}$-dependent enzymes, alterations of the cytoskeleton, mitochondrial damage, and by the activation of irreversible catabolic processes which may ultimately result in cell death (Nicotera et al., 1992; Stohs and Bagchi, 1995; Nicotera and Orrenius, 1998). A diverse range of natural and anthropogenic chemicals such as divalent heavy metal ions, bromophenols, bisphenol A as well as polycyclic aromatic hydrocarbons have been shown to interfere with cellular $\mathrm{Ca}^{2+}$ signalling (e.g. Büsselberg et al., 1990; Davila et al., 1995; Stohs and Bagchi, 1995; Nielsen et al., 2003; Wozniak et al., 2005).

At fertilization, eggs undergo an increase in intracellular $\mathrm{Ca}^{2+}$ beginning at the point of sperm-egg fusion and crossing the egg to the antipode in a wave-like fashion (Santella et al., 2004; Whitaker, 2006). This calcium wave is the first event at fertilization triggering the quiescent egg into metabolic activity by posttranslational activation of

\footnotetext{
* Corresponding author. Tel.: +49 4714831 1407; fax: +49 47148311425 .

E-mail address: Angela.Koehler@awi.de (A. Koehler).
}

enzymes, exocytosis of cortical granules for formation of the fertilization membrane and resumption of the cell cycle (Covian-Nares et al., 2004; Santella et al., 2004).

In the following paragraph a selection of chemicals interfering with cellular $\mathrm{Ca}^{2+}$ signalling and homeostasis are presented: $\mathrm{Cu}^{2+}$ is an essential metal ion required for metabolic processes in all eukaryotes but can reach toxic levels in aquatic environments (Bryan and Langston, 1992; Stohs and Bagchi, 1995; Zorita et al., 2006). $\mathrm{Cu}^{2+}$ has been shown to alter $\mathrm{Ca}^{2+}$ signals in developing embryos of the macroalgae Fucus serratus (Nielsen et al., 2003). Bromophenols are industrially produced flame retardant intermediates and wood preservatives (Howe et al., 2005) which also occur naturally in the marine environment in algae (Whitfield et al., 1999) as well as in fish and invertebrates (Boyle et al., 1992; Fielman et al., 2001). Recently, bromophenols such as 2,4,6tribromophenol have been shown to disturb cellular $\mathrm{Ca}^{2+}$-signalling in neuroendocrine cells (Hassenklöver et al., 2006). Bisphenol A, an important key monomer in the production of polycarbonate plastics and epoxy resins, and endocrine disruptor, affects $\mathrm{Ca}^{2+}$ homeostasis by provoking $\mathrm{Ca}^{2+}$ influx via $\mathrm{Ca}^{2+}$ channels in mammalian tumor cell lines (Wozniak et al., 2005). Further, in goldfish bisphenol A significantly altered plasma $\mathrm{Ca}^{2+}$ levels (Suzuki et al., 2003). Polycyclic aromatic hydrocarbons (PAHs) are ubiquitous environmental pollutants contained in petroleum hydrocarbons and formed during combustion of fossil fuels and other products (Latimer and Zheng, 2003). PAHs and its metabolites have been shown to alter $\mathrm{Ca}^{2+}$-associated signalling 
pathways in immune (Davila et al.,1995) and nonimmune cells (Barhoumi et al., 2006) as well as in isolated membrane vesicles of mammalian skeletal muscles (Pessah et al., 2001).

Sea urchins are widely used to study the cellular events at fertilization (Santella et al., 2004; Whitaker, 2006). Further, some natural and anthropogenic chemicals have been tested on $\mathrm{Ca}^{2+}$ homeostasis in sea urchin eggs (Walter et al., 1989; Pesando et al., 1991, 1996; Girard et al., 1997). Thereby, the permeability of the plasma membrane to $\mathrm{Ca}^{2+}$ and other ions as well as the accumulation and release of sequestered $\mathrm{Ca}^{2+}$ were assessed (Pesando et al., 1991, 1996; Girard et al., 1997). Walter et al. (1989) investigated the $\mathrm{Ca}^{2+}$ content and uptake of $\mathrm{Ca}^{2+}$ as well as the role of mitochondrial damage in sea urchin eggs upon exposure to mercury chloride.

In sea urchins and some other organisms the calcium wave represents a single event which is followed by a few minor rises in the intracellular concentration of $\mathrm{Ca}^{2+}$ ions (Stricker, 1999). The mechanisms by which the sperm triggers $\mathrm{Ca}^{2+}$ release at fertilization are still under debate (Santella et al., 2004). In the most established model the sperm is believed to introduce a sperm factor into the egg promoting the formation of inositol-1,4,5-triphosphate $\left(\mathrm{InsP}_{3}\right)$ which initiates the activating $\mathrm{Ca}^{2+}$ wave (Jaffe et al., 2001; Santella et al., 2004). Studies indicate that in sea urchins there are two further messengers of $\mathrm{Ca}^{2+}$ signalling: nicotinic acid adenine dinucleotide phosphate (NAADP) and cyclic ADP ribose (cADPr) giving the fertilization calcium wave a boost and longevity (Steinhardt et al., 1977; Whitaker, 2006). Steinhardt et al. (1977) and Schmidt et al. (1982) have shown that the
$\mathrm{Ca}^{2+}$ is released from intracellular stores, whereby later $\mathrm{InsP}_{3}$ and $\mathrm{cADPr}$ were identified for mobilizing $\mathrm{Ca}^{2+}$ from the endoplasmic reticulum (reviewed by Galione, 1994, Jaffe et al., 2001). In contrast, NAADP is known to induce $\mathrm{Ca}^{2+}$ release from lysosomes (Churchill et al., 2002).

Calcium signals are mostly measured using fluorescent calcium indicator dyes (Whitaker, 2006). The ratiometric fluorescent dye Fura-2 has already been used for measuring the calcium wave at fertilization in eggs of the sea urchin Lytechinus pictus (Poenie et al., 1985; Swann and Whitaker, 1986) as well as in ascidians and mammals (Hyslop et al. 2001; Carroll et al., 2003). In general, the dyes are microinjected into the eggs. Indeed, Fura-2 is also available as membrane permeable acetoxymethylester Fura-2 AM. After crossing the membrane Fura-2 AM is quickly hydrolyzed by intracellular esterases to produce membrane impermeable Fura-2. Previously, the inhibitor for multidrug resistance associated proteins (MRP) MK571 has been shown to enhance uptake of fluorescent dyes in animal cells (Manzini and Schild, 2003; Bickmeyer et al., 2008) as well as in diatoms (Scherer et al., 2008). MRPs are efflux transporters of the ATP Binding Casette (ABC) superfamily actively transporting and sequestering endogenous and exogenous compounds (Holland and Blight, 1999; Leslie et al., 2001). In marine invertebrates MRPs have been demonstrated to be expressed in marine bivalve mollusks as well as in sea urchins (Hamdoun et al., 2004; Lüdeking et al., 2005).

The aim of the present study was to test if chemicals may alter the calcium wave at fertilization in sea urchins. For this purpose, the heavy metals $\mathrm{Cu}^{2+}$ and $\mathrm{Pb}^{2+}$, the bromophenol 2,4,6-tribromophenol, bisphenol $\mathrm{A}$, and the polycyclic aromatic hydrocarbon phenanthrene a)

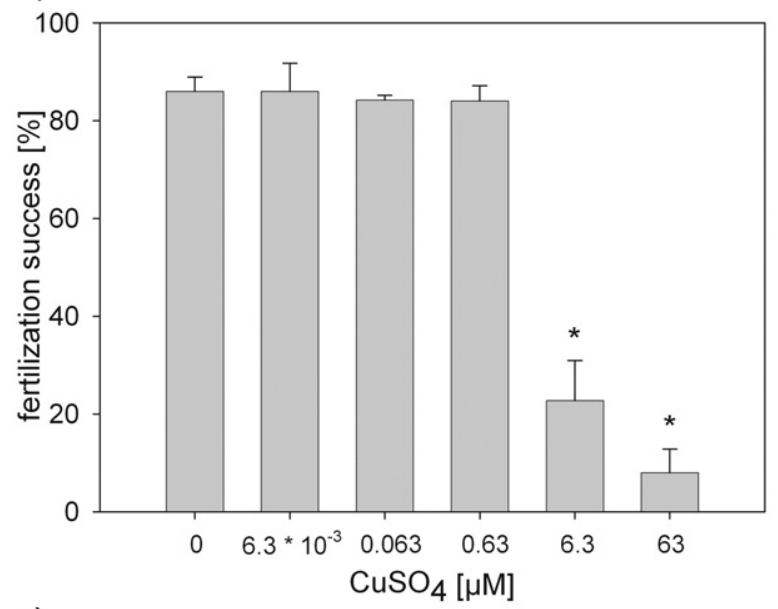

c)

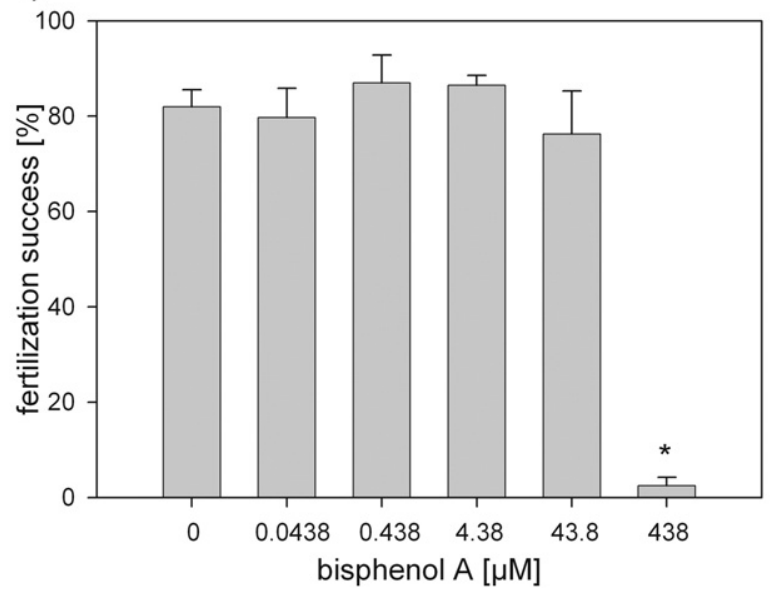

b)

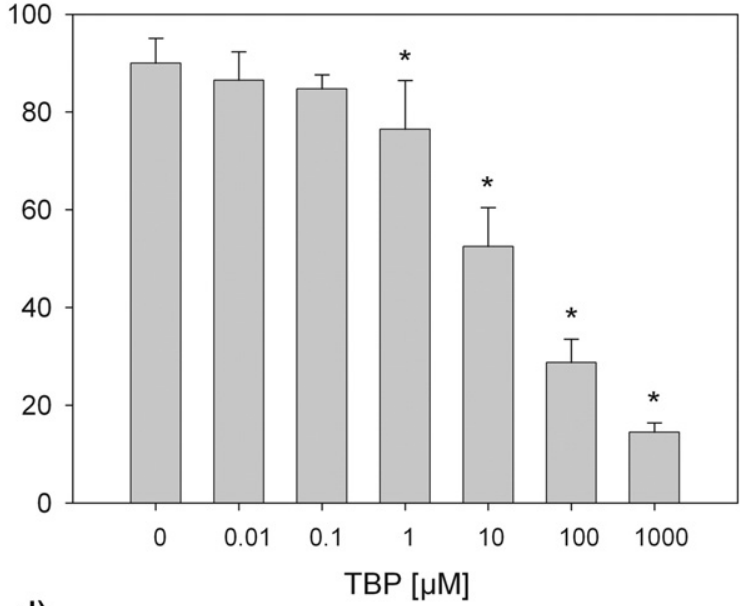

d)

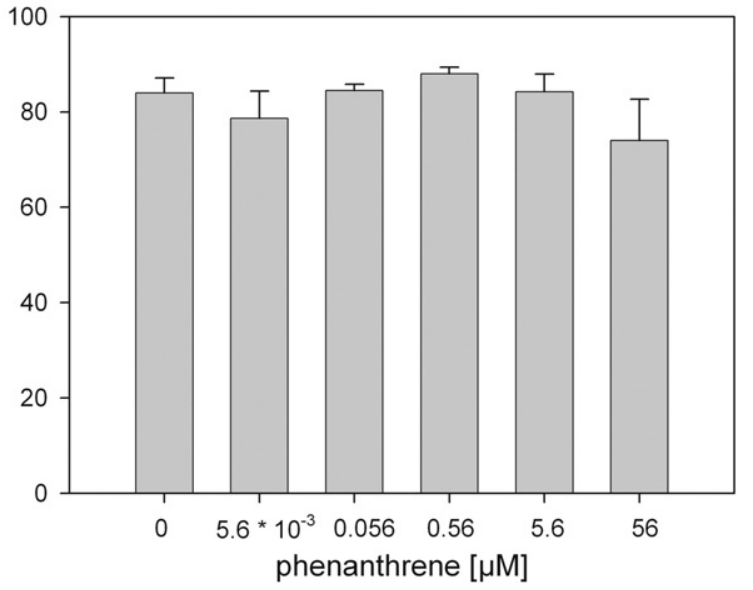

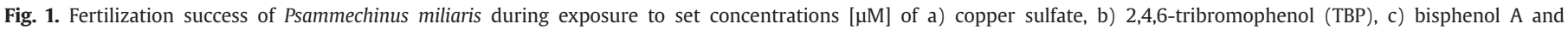

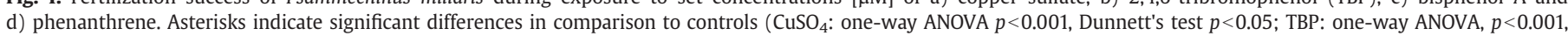
Dunnett's test $p<0.05$; Bisphenol A: one-way ANOVA $p<0.001$, Dunnett's test $p<0.05$; Phenanthrene: Kruskal-Wallis ANOVA on ranks $p=0.074$ ). 
were tested for their potential to inhibit fertilization success of the sea urchin Psammechinus miliaris. We measured the calcium wave at fertilization using Fura-2 AM and the MRP inhibitor MK571.

\section{Materials and methods}

\subsection{Animal collection and maintenance}

P. miliaris were collected by fishing subtidal populations close to the Island Sylt (Germany) by a beam trawl with the FK Uthörn in April 2008. Sea urchins were transported to the Biological Institute Helgoland where they were kept in running sea water at ambient temperature until use.

\subsection{Collection and processing of gametes}

P. miliaris were induced to spawn by injection of $0.5 \mathrm{~mL} 0.5 \mathrm{M} \mathrm{KCl}$. Sperm was collected from the aboral pore of each individual using a syringe fitted to a needle and stored 'dry' on ice until use. Female sea urchins were induced to spawn in the same way, but eggs were released directly into artificial sea water. Gametes were collected during the first 20 min of spawning. The quality of eggs was assessed microscopically on the basis of uniformity of shape and size.

\subsection{In vitro fertilization assays}

The following chemicals were tested on fertilization success of P. miliaris: copper sulfate $\left(\mathrm{CuSO}_{4} \times 5 \mathrm{H}_{2} \mathrm{O}\right), 2,4,6$-tribromophenol (TBP), bisphenol A and phenanthrene. $1000 \times$ concentrated stock solutions were prepared in distilled water (copper sulfate), DMSO (phenanthrene, bisphenol A), or methanol (2,4,6-tribromophenol). Concentration ranges of test substances were selected according to His et al. (1999), King and Riddle (2001) and Fernández and Beiras (2001) for copper, Hassenklöver and Bickmeyer (2006) and Hassenklöver et al. (2006) for TBP, Roepke et al. (2005) and Kiyomoto et al. (2006) for bisphenol A and Steevens et al. (1999) and Pillai et al. (2003) for phenanthrene. Eggs and sperm were obtained as described above but eggs were released in general purpose medium 2 (GP 2: $360 \mathrm{mM} \mathrm{NaCl}, 24.8 \mathrm{mM} \mathrm{Na}_{2} \mathrm{SO}_{4}, 8.2 \mathrm{mM} \mathrm{KCl}$, $0.74 \mathrm{mM} \mathrm{KBr}, 0.09 \mathrm{mM} \mathrm{Na}_{2} \mathrm{~B}_{4} \mathrm{O}_{7} \times 10 \mathrm{H}_{2} 0,46.7 \mathrm{mM} \mathrm{MgCl} 2 \times 6 \mathrm{H}_{2} \mathrm{O}, 11.9$ $\mathrm{CaCl}_{2} \times 2 \mathrm{H}_{2} \mathrm{O}, 0.08 \mathrm{mM} \mathrm{SrCl}_{2} \times 6 \mathrm{H}_{2} \mathrm{O}, 2.02 \mathrm{mM} \mathrm{NaHCO}_{3}$ ) (instead of ASW) which had been aerated for $24 \mathrm{~h}$ (U.S. EPA, 1993; Caldwell et al., 2002). During fertilization assays it is essential to keep the concentrations of sperm and eggs constant in the different treatments and replicates. In preliminary experiments (data not shown) in vitro fertilization without exposing the sperm was not satisfactory since washing and counting of the eggs took too long and resulted in low egg quality with insufficient fertilization rates in controls. Therefore, eggs as well as sperm - though only for a short period - were exposed to the test substances during fertilization assays. Thus, reduced fertilization success may be the result of toxicity on both types of gametes.

Eggs from three to four females were pooled and sperm from two to three males were pooled (U.S. EPA, 1993). Approximately 200 unfertilized eggs of the pooled egg suspension were stocked in $1 \mathrm{~mL}$ medium in polystyrene 24 well microplates. Eggs were incubated at $18{ }^{\circ} \mathrm{C}$ either with the test substances at set concentrations or with the respective controls (distilled water, DMSO, or methanol). Solvents had a)

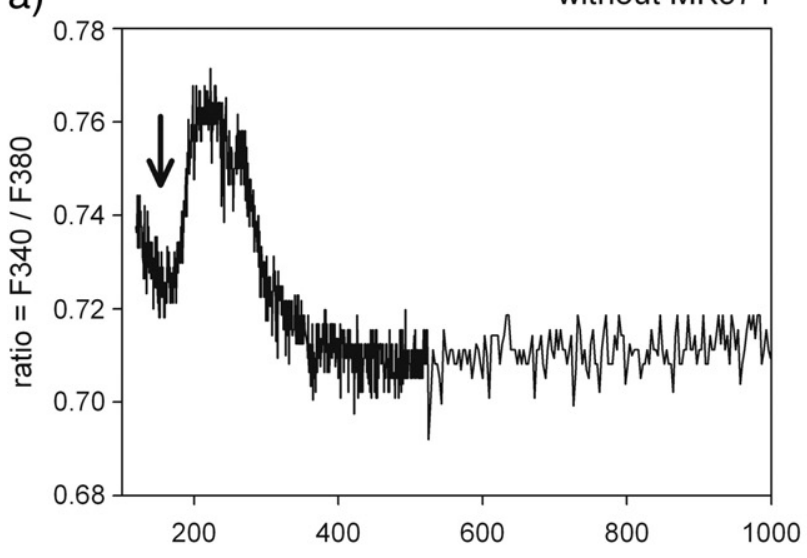

c)

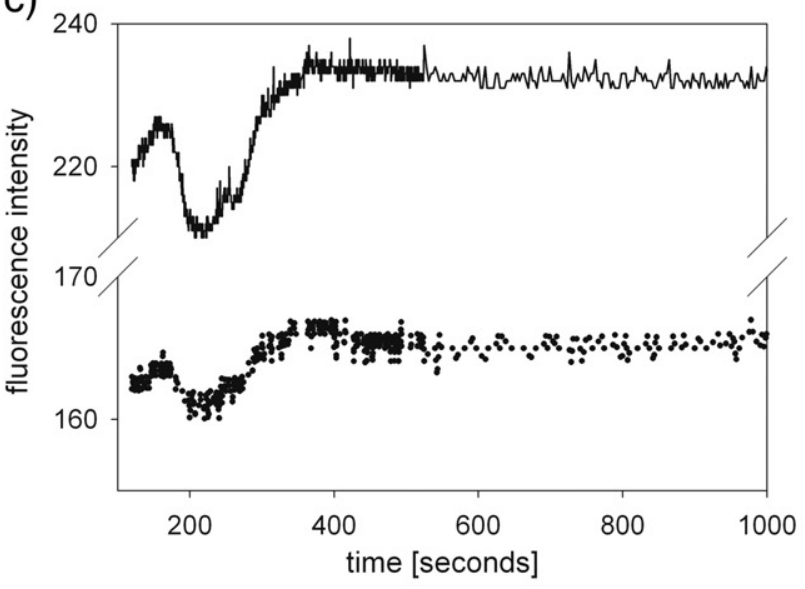

b)

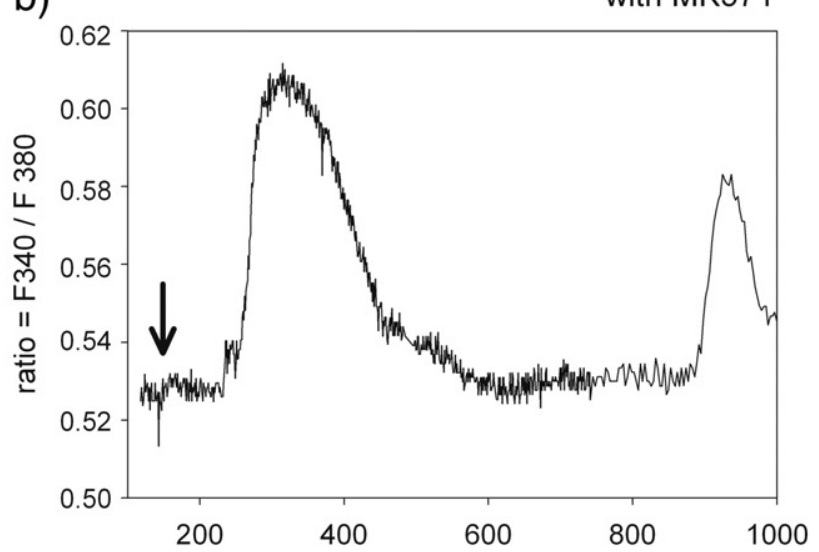

d)

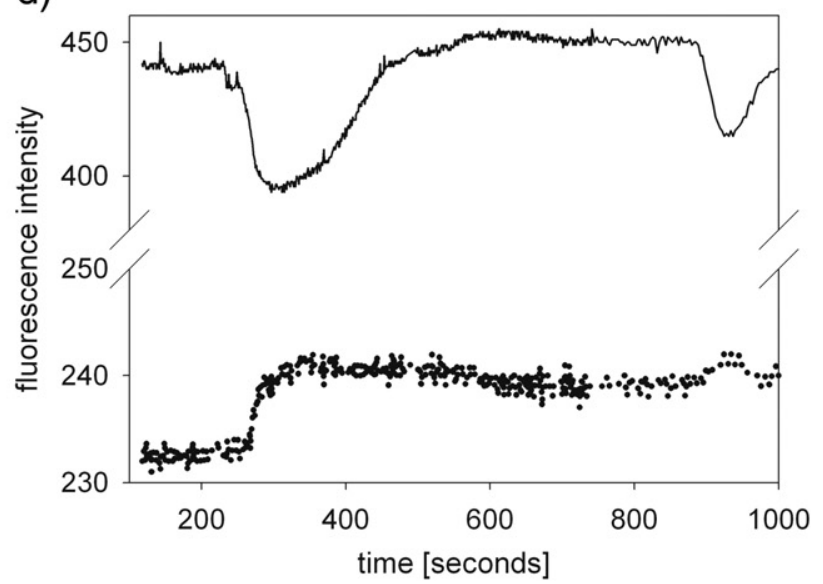

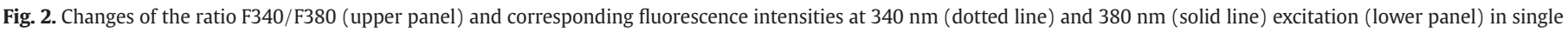

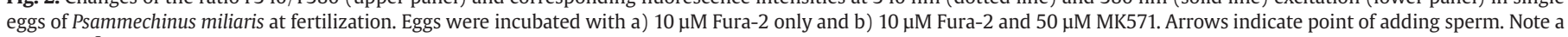
second $\mathrm{Ca}^{2+}$ rise approximately $400 \mathrm{~s}$ after the first peak in b). 

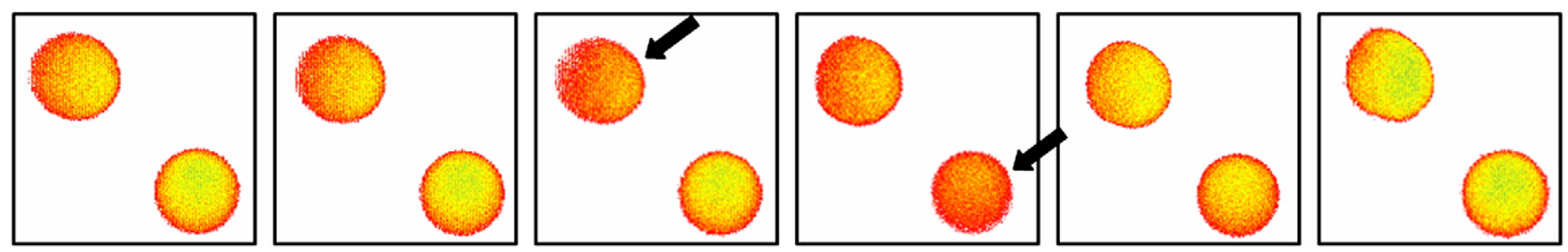

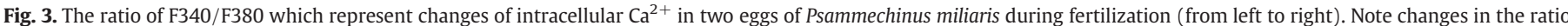

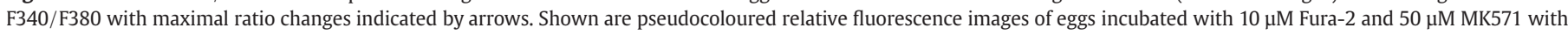
high fluorescence intensities in red and low in green, respectively.

a final concentration of $0.1 \%$ in all wells. Four replicate incubations were run per treatment. After $60 \mathrm{~min}, 10 \mu \mathrm{L}$ of sperm suspension in GP2 were added to give a final sperm concentration of $2.5 \times 10^{6} \mathrm{~mL}^{-1}$ (Caldwell et al., 2002). Sperm had been allowed to activate in GP2 approximately $10 \mathrm{~min}$ prior to use. The plates were gently agitated for $30 \mathrm{~s}$ to increase sperm/egg encounters and incubated for $15 \mathrm{~min}$. Fertilization was stopped by adding $100 \mu \mathrm{L}$ \%\% formaldehyde in ASW. The final concentration of formaldehyde is sufficient to stop fertilization (U.S. EPA, 1993) which was evident by amotile sperm and the absence of multi-cellular embryos in the wells. Fertilization success was determined using an inverted microscope (Axiovert 25, Zeiss, Germany) and was defined as elevation of the fertilization membrane observed at $100 \times$ magnification. 100 eggs per well were counted and the number of unfertilized eggs were recorded.

a)

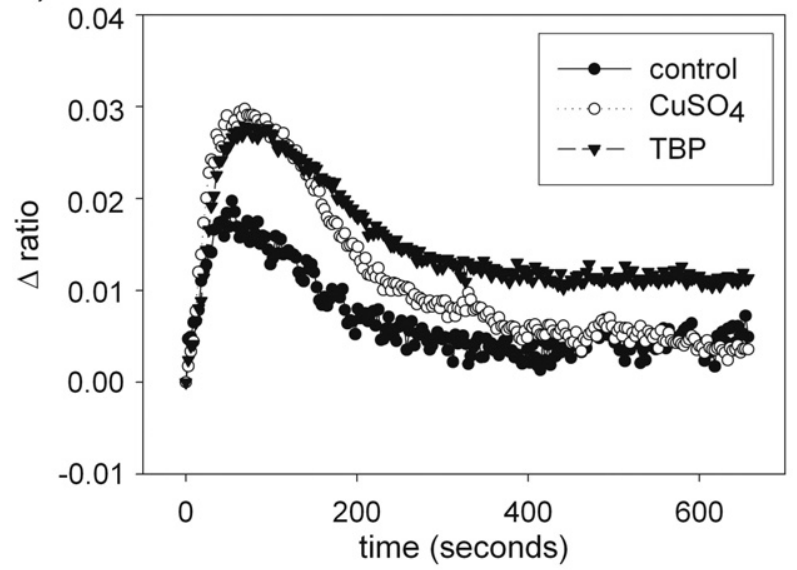

c)

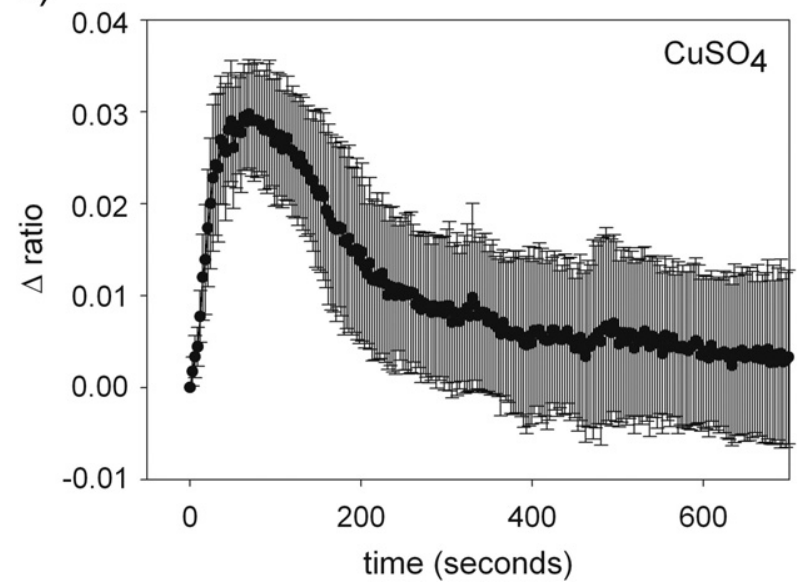

\subsection{Fluorometric measurement of intracellular $\mathrm{Ca}^{2+}$ levels at fertilization}

For measuring $\mathrm{Ca}^{2+}$ signals at fertilization, gametes were obtained as described above but for each test eggs from one female and sperm from one male were used (gametes were not pooled). Eggs were incubated with artificial seawater (ASW: $460 \mathrm{mM} \mathrm{NaCl}, 10.4 \mathrm{mM} \mathrm{KCl}$, $55 \mathrm{mM} \mathrm{MgCl} \times 6 \mathrm{H}_{2} 0,11 \mathrm{mM} \mathrm{CaCl} 2,15 \mathrm{mM}$ Hepes-Na; pH 7.5) containing either $10 \mu \mathrm{M}$ Fura- 2 AM or $10 \mu \mathrm{M}$ Fura-2 AM with $50 \mu \mathrm{M}$ MK571 for $60 \mathrm{~min}$ at room temperature. Eggs were washed three times with ASW. They were fertilized by adding sperm which was activated by dilution of dry sperm in ASW immediately prior to use.

Fluorescence of eggs during in vitro fertilization was monitored by an imaging system (Visitron, Puchheim, Germany) with a CCD camera

b)

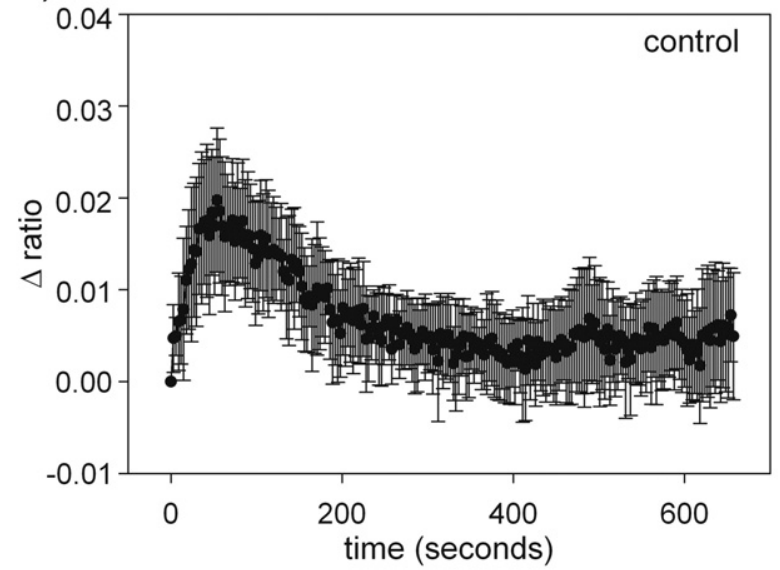

d)

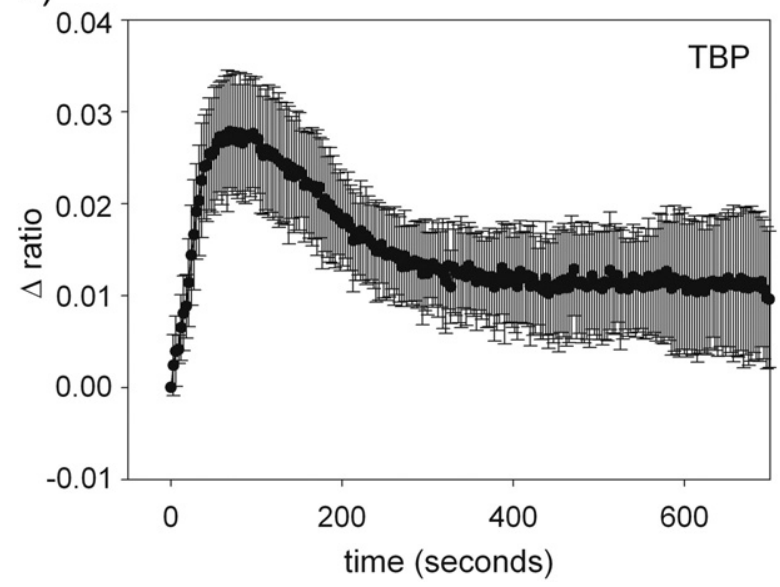

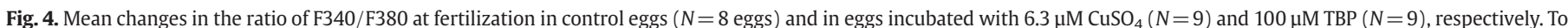

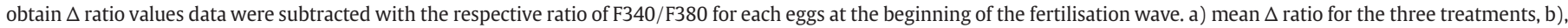

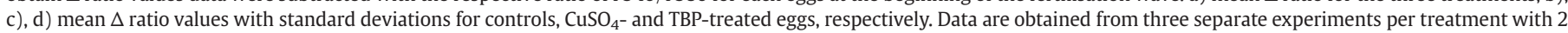
to 4 eggs each. 
(Coolsnap) mounted on an inverted microscope (Axiovert 100, Zeiss). Two to four eggs were measured simultaneously by using the 'region of interest' function of the software (Metafluor, Meta Imaging Series). Fluorescence was obtained through an UV objective (NeoFluar 20x, Zeiss). Data were obtained from division of two images, one obtained at $340 \mathrm{~nm}$, the other at $380 \mathrm{~nm}$ excitation. Obtained ratio values were not converted to intracellular $\mathrm{Ca}^{2+}$ concentrations.

\subsection{The effects of $\mathrm{Cu}^{2+}$ and TBP on $\mathrm{Ca}^{2+}$-signalling in eggs}

Gametes were obtained as described for the fluorometric measurements. In contrast to in vitro fertilization assays, counting of eggs is not necessary during fluorometric measurement of intracellular $\mathrm{Ca}^{2+}$ levels. Therefore, eggs were washed prior to addition of sperm so that only the eggs were exposed to the tested chemicals.

First, eggs were incubated in medium (GP2) with $10 \mu \mathrm{M}$ Fura-2 $\mathrm{AM}$ and $50 \mu \mathrm{M}$ MK571 for $60 \mathrm{~min}$ and washed three times with GP2. Test substances $\left(6.3 \mu \mathrm{M} \mathrm{Cu}^{2+}\right.$ or $100 \mu \mathrm{M}$ TBP) were added and fluorescence was recorded as described above. Next, it was tested whether the test substances lead to alterations of the calcium wave at fertilization of $P$. miliaris. To avoid interference of the MRP inhibitor on the toxicity of the test substances, eggs were treated with the test substances first and incubated with Fura-2 AM and MK571 afterwards. In detail, eggs were incubated with test substances $\left(6.3 \mu \mathrm{M} \mathrm{Cu}^{2+}\right.$ or $100 \mu \mathrm{M}$ TBP) for $60 \mathrm{~min}$, washed three times with GP2, and then incubated with $10 \mu \mathrm{M}$ Fura-2 AM and $50 \mu \mathrm{M}$ MK571 for $60 \mathrm{~min}$ and washed again three times with GP2. Eggs were fertilized with $10 \mu \mathrm{L}$ sperm suspension (dry sperm diluted 1:50 immediately prior to use) and fluorescence was recorded. Two to four eggs were recorded simultaneously and at least three experiments were run per treatment. Incubation of eggs and tests were performed at $18^{\circ} \mathrm{C}$.

\subsection{Statistics}

Statistical tests were run with Sigma Stat 3.0 (SPSS Inc.). Residuals were tested for normality and variance homogeneity. Data for fertilization rates were arc sin square root transformed and a one-way ANOVA with a Dunnett's test as post hoc test was run as described by the U.S. EPA (1993) for sea urchin fertilization tests. In case the data were not normally distributed a Kruskal-Wallis ANOVA on ranks was used. The $\mathrm{Ca}^{2+}$ signals (the $\Delta$ ratio $_{\max }$ and the time needed to reach maximal changes in the $\mathrm{Ca}^{2+}$ signal) were analysed with a one-way ANOVA and a Dunnett's test. The significance level was set at $p<0.05$. Note that in Sigma Stat 3.0 the $p$-values for the Dunnett's test are unavailable. The software only indicates if the $p$-value is above or below the significance level of 0.05 .

\section{Results}

\subsection{In vitro fertilization assays}

In Fig. 1 the fertilization rates of $P$. miliaris after exposure to the test substances are presented. Exposure to $\mathrm{Cu}^{2+}$ significantly reduced fertilization success of $P$. miliaris at the two highest concentrations (6.3 and $63 \mu \mathrm{M}$, one-way ANOVA, $p<0.001$ ). $63 \mu \mathrm{M} \mathrm{Cu}^{2+}$ significantly decreased the fertilization rate by $76 \%$ in comparison to controls. TBP significantly inhibited fertilization success of $P$. miliaris at $1 \mu \mathrm{M}$ (oneway ANOVA, $p<0.001$ ). Exposure to $1000 \mu \mathrm{M}$ TBP, the highest concentration tested, significantly inhibited the fertilization rate by $75 \%$ in comparison to controls. $438 \mu \mathrm{M}$ bisphenol A significantly reduced fertilization success by $97 \%$ in comparison to controls. (one-way ANOVA, $p<0.001$ ). Indeed, for bisphenol A no effects were found at concentrations lower than $438 \mu \mathrm{M}$. Phenanthrene showed no effect on fertilization success at concentrations of up to $56 \mu \mathrm{M}$ (Kruskal-Wallis ANOVA on ranks, $p=0.074$ ).

\subsection{Fluorometric measurement of intracellular $\mathrm{Ca}^{2+}$} levels at fertilization

In the experiments, eggs of $P$. miliaris were successfully fertilized by adding activated sperm, which was checked visually after each experiment by elevation of the fertilization membrane. However, after incubation with Fura-2 AM no calcium signals could be observed in the eggs during fertilization ( $N=8$ eggs measured in three separate experiments). In some cases, an increase in the ratio F340/F380 was recorded. Indeed, close inspection of the corresponding fluorescence intensities at 340 and $380 \mathrm{~nm}$ excitation shows that the ratio changes are due to decreasing intensities at both wavelengths induced by cell movement during fertilization (see Fig. 2a). These changes cannot be regarded as alterations in intracellular $\mathrm{Ca}^{2+}$ since the fluorescence spectrum of Fura-2 does not shift in opposite directions with an increase at 340 and a decrease at $380 \mathrm{~nm}$.

In contrast, after incubation with Fura-2 AM and MK571 clear calcium waves could be observed in the eggs upon fertilization (Fig. 3 ) ( $N=8$ eggs measured in 4 separate experiments). The changes in the ratio of F340/F380 clearly correspond to changes in intracellular $\mathrm{Ca}^{2+}$ since the fluorescence intensity increases at $340 \mathrm{~nm}$ and decreases at $380 \mathrm{~nm}$ excitation (Fig. 2b). The ratio of F340/F380 changed by $0.033 \pm$ 0.02 in comparison to the resting ratio level before fertilization $(N=8)$. The calcium waves reached their maximum after $95 \pm 33 \mathrm{~s}$ and lasted $351 \pm 130 \mathrm{~s}(N=8)$.

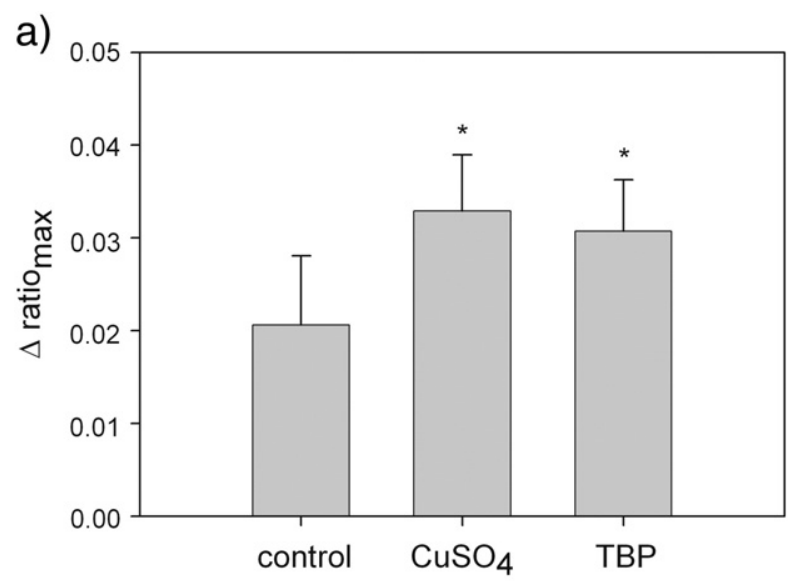

b)

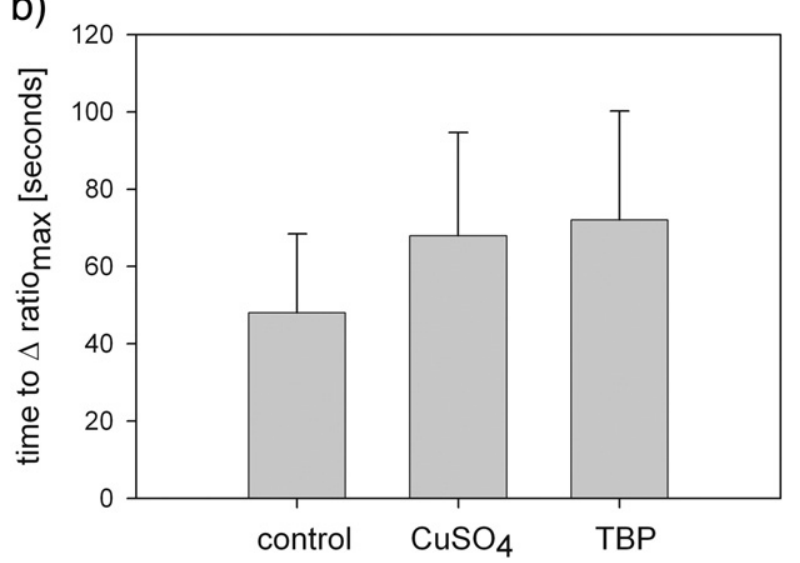

Fig. 5. a) Maximal changes in the ratio F340/F380 at fertilization in control ( $N=8$ eggs), $\mathrm{CuSO}_{4^{-}}(N=9)$ and TBP-treated $(N=9)$ eggs. Asterisks indicate significant differences in comparison to controls (one-way ANOVA, $p<0.001$, Dunnett's test $p<0.05$ ). b) The time [s] needed to reach maximal changes in the ratio F340/F380 at fertilization in control, $\mathrm{CuSO}_{4-}$ and TBP-treated eggs. No significant differences were found in comparison to controls (one-way ANOVA, $p=0.143$ ). Data are obtained from three separate experiments per treatment with 2 to 4 eggs each. 
In one egg, a second $\mathrm{Ca}^{2+}$ rise was observed 10 min after the first peak (Fig. 2b) which was around 70\% smaller and with 177 s shorter than the first peak with $371 \mathrm{~s}$.

\subsection{The effects of $\mathrm{Cu}^{2+}$ and TBP on $\mathrm{Ca}^{2+}$-signalling in eggs}

For the following experiments $6.3 \mu \mathrm{M}$ copper sulfate and $100 \mu \mathrm{M}$ TBP were selected which inhibited fertilization success by $65 \%$ and $61 \%$, respectively, in comparison to controls. Neither $6.3 \mu \mathrm{M} \mathrm{Cu}^{2+}$ nor $100 \mu \mathrm{M}$ TBP induced detectable calcium signals in unfertilized eggs (data not shown). After incubation of eggs with $\mathrm{Cu}^{2+}$ and TBP the fertilizing sperm still induced a $\mathrm{Ca}^{2+}$ wave. In Fig. 4 mean relative changes in the ratio of F340/F380 at fertilization, $\Delta$ ratio, obtained after subtracting the resting ratio of F340/F380 prior to fertilization are shown in the different treatments. Eggs treated with $\mathrm{Cu}^{2+}$ and TBP exhibited alterations of the fertilization calcium wave: The maximal changes in the ratio F340/F380 (the $\mathrm{Ca}^{2+}$ peak) were significantly higher in $\mathrm{Cu}^{2+}$ - and TBP-treated eggs in comparison to controls (Fig. 5a). In TBP-treated eggs the $\Delta$ ratio remained above the resting ratio prior to fertilization within $600 \mathrm{~s}$ after fertilization whereas in control and $\mathrm{Cu}^{2+}$-treated eggs the $\Delta$ ratio fell to resting levels approximately $400 \mathrm{~s}$ after fertilization. In addition, the $\Delta$ ratio showed a high variance in $\mathrm{Cu}^{2+}$-treated eggs after the fertilization $\mathrm{Ca}^{2+}$ wave. Indeed, the time needed to reach the maximal changes in the ratio was not different in the treatments (Fig. 5b).

In eggs of all treatments, small postfertilization $\mathrm{Ca}^{2+}$ rises could be observed within 12 min postfertilisation (control: 15 postfertilization waves, $\mathrm{Cu}^{2+}: 5$, TBP: 12). In controls up to four and in $\mathrm{Cu}^{2+}$ - and TBPtreated eggs up to two postfertilization $\mathrm{Ca}^{2+}$ waves were recorded, respectively.

\section{Discussion}

So far, studies on the fertilization $\mathrm{Ca}^{2+}$ wave have focused on the North American sea urchin species Lytechinus pictus and Strongylocentrotus purpuratus. Though, Genazzani et al. (1999) have demonstrated that egg homogenates of $P$. miliaris share the same $\mathrm{Ca}^{2+}$ release mechanisms as L. pictus and S. purpuratus with the InsP $\mathrm{P}_{3}$, the cADRP and the NAADP pathways. In L. pictus, the $\mathrm{Ca}^{2+}$ wave at fertilization is reported to reach its peak after approximately $20 \mathrm{~s}$ (Poenie et al., 1985, Swann and Whitaker, 1986), while in the present study, the $\mathrm{Ca}^{2+}$ rise in P. miliaris takes approximately $95 \mathrm{~s}$ to reach its maximum. However, the duration of the $\mathrm{Ca}^{2+}$ transients are comparable with approximately 5 min in L. pictus measured by Poenie et al. (1985) and in P. miliaris in the present study.
Different developmental stages of marine invertebrates are known to be affected differently by chemicals or polluted water samples with fertilization being either more or less sensitive than embryonic and larval development (e.g. Kobayashi, 1980, 1990; Gopalakrishnan et al., 2008). By comparing toxicity of chemicals on different life stages exposure times towards test substances often differ and make a direct comparison difficult. In the present study, fertilization success of $P$. miliaris was inhibited by bisphenol A only at the highest concentration $(438 \mu \mathrm{M})$ tested. Phenanthrene did not affect fertilization rates of $P$. miliaris up to $56 \mu \mathrm{M}$. Yet, these values are above critical concentrations reported to affect sea urchin embryonic and larval development (Table 1). Furthermore, the effective concentration of phenanthrene is above its 'safe' level of $<=29 \mathrm{nM}$ developed by several countries for aquatic organisms (Law et al., 1997). To our knowledge, no maximum permissible value has been set for bisphenol $A$ in the aquatic environment.

We show that fertilization success of $P$. miliaris was significantly affected at $6.3 \mu \mathrm{M} \mathrm{Cu}^{2+}$. The same concentration increased the calcium wave at fertilization indicating disturbance of $\mathrm{Ca}^{2+}$ homeostasis in the eggs by exposure to $\mathrm{Cu}^{2+}$. Early life history stages of marine invertebrates may be particularly sensitive to elevated copper concentrations (Kobayashi, 1980, 1990; Bielmyer et al., 2005, Table 1). Generally, divalent heavy metals are known to affect cellular calcium homeostasis (Stohs and Bagchi, 1995). Exposure of sea urchin eggs towards the heavy metal mercury chloride increased calcium influx and calcium content in a time and dose-dependent manner resulting in disturbance of mitochondrial function and finally cell death (Walter et al., 1989). In sperm of the mussel Mytilus edulis treated with $3.3 \mathrm{mM}$ $\mathrm{Cu}^{2+} \mathrm{Ca}^{2+}$ levels significantly decreased in mitochondria and acrosomes indicating an increase in the ionic permeability of organelle membranes and possibly resulting in an increase in cytosolic $\mathrm{Ca}^{2+}$ (Earnshaw et al., 1986). $\mathrm{Ca}^{2+}$ channels on the sperm plasma membrane have also been proposed to be affected after paternal exposure of sea urchins to the heavy metal $\mathrm{Cd}^{2+}$ (Au et al., 2001). Further, $\mathrm{Cu}^{2+}$ has been shown to alter $\mathrm{Ca}^{2+}$ signals in developing embryos of the macroalgae Fucus serratus: Moderate $\mathrm{Cu}^{2+}$ concentrations (422 nM) inhibited generation of cytosolic $\mathrm{Ca}^{2+}$ signals in response to hypoosmotic shock whereas high $\mathrm{Cu}^{2+}$ concentrations $(2.11-8.44 \mu \mathrm{M})$ elevated cytosolic $\mathrm{Ca}^{2+}$ (Nielsen et al., 2003).

Next to $\mathrm{Cu}^{2+}$, TBP significantly decreased fertilization success of $P$. miliaris in a dose-dependent manner in our study. Recently, bromophenols have been shown to inhibit larval survival and metamorphosis of the sea urchin Strongylocentrotus nudus (Agatsuma et al., 2008, Table 1). In the present study, TBP significantly decreased fertilization success of $P$. miliaris at $10 \mu \mathrm{M}$. Moreover,

Table 1

Toxicities of test substances on different species of sea urchins (Echinoidea).

\begin{tabular}{|c|c|c|c|c|c|c|}
\hline Test substance & Species & $\begin{array}{l}\text { Effective } \\
\text { concentration }\end{array}$ & Duration of exposure & $\begin{array}{l}\text { Developmental } \\
\text { stage }\end{array}$ & Effect & Reference \\
\hline \multirow[t]{3}{*}{ Bisphenol A } & $\begin{array}{l}\text { Strongylocentrotus } \\
\text { purpuratus }\end{array}$ & $1 \mu \mathrm{M}$ & $96 \mathrm{~h}$ & Embryos-larvae & EC50 for normal development & Roepke et al. (2005) \\
\hline & $\begin{array}{l}\text { Hemicentrotus } \\
\text { pulcherrimus }\end{array}$ & $\geq 10 \mu \mathrm{M}$ & $\begin{array}{l}\text { Directly after until up to } \\
48 \text { h postfertilization }\end{array}$ & Embryos-larvae & Suppression of development & Kiyomoto et al. (2006) \\
\hline & $\begin{array}{l}\text { Hemicentrotus } \\
\text { pulcherrimus }\end{array}$ & $\geq 10 \mu \mathrm{M}$ & $12 \mathrm{~h}$ after fertilization & Embryos-larvae & No effect on development & Kiyomoto et al. (2006) \\
\hline \multirow[t]{4}{*}{ Copper } & $\begin{array}{l}\text { Heliocidaris } \\
\text { erythrogramma }\end{array}$ & $\geq 4 \mathrm{nM}$ & & Sperm-eggs & $\begin{array}{l}\text { Reduced fertilization success, } \\
\text { (most sensitive among five tested } \\
\text { sea urchin species) }\end{array}$ & Kobayashi (1980) \\
\hline & Diadema antillarum & $44 \mathrm{nM}$ & $40 \mathrm{~h}$ & Embryos-larvae & EC50 for abnormal development & Bielmyer et al. (2005) \\
\hline & Paracentrotus lividus & $\geq 0.25 \mu \mathrm{M}$ & $48 \mathrm{~h}$ & Embryos-larvae & Inhibition of growth & Fernández and Beiras \\
\hline & Paracentrotus lividus & $1.1 \mu \mathrm{M}$ & $48 \mathrm{~h}$ & Embryos-larvae & EC50 for complete development & (2001) \\
\hline \multirow[t]{2}{*}{ Phenanthrene } & Lytechinus variegatus & $\geq 6 \mathrm{nM}$ & $2 \mathrm{~h}$ & Eggs-embryos & $\begin{array}{l}\text { Inhibition of embryo } \\
\text { development }\end{array}$ & Steevens et al. (1999) \\
\hline & Lytechinus anemensis & $\geq 1 \mu \mathrm{M}$ & n.st. & Embryos & Disruption of axial development & Pillai et al. (2003) \\
\hline $2,4,6-$ & Strongylocentrotus nudus & $\geq 3 \mathrm{nM}$ & $1 \mathrm{~h}$ & Larvae & Inhibition of metamorphosis & Agatsuma et al. (2008) \\
\hline \multirow[t]{2}{*}{ Tribromophenol } & Strongylocentrotus nudus & $\geq 30 \mathrm{nM}$ & $24 \mathrm{~h}$ & Larvae & Inhibition of swimming activity & Agatsuma et al. (2008) \\
\hline & Strongylocentrotus nudus & $150 \mathrm{nM}$ & $24 \mathrm{~h}$ & Larvae & Mortality & Agatsuma et al. (2008) \\
\hline
\end{tabular}

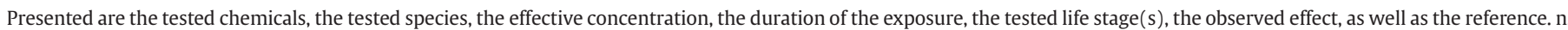
st. $=$ not stated. 
exposure of eggs to $100 \mu \mathrm{M}$ TBP significantly increased the $\mathrm{Ca}^{2+}$ wave at fertilization indicating alterations of calcium signalling by TBP. An increase in intracellular $\mathrm{Ca}^{2+}$ partly by $\mathrm{Ca}^{2+}$ release from intracellular stores after exposure to TBP has already been shown in neuroendocrine (PC12) cells (Hassenklöver et al., 2006). In a subsequent study, Hassenklöver and Bickmeyer (2006) show that TBP selectively reduced calcium channel currents in PC12 cells with a half-maximal concentration of $28 \pm 18 \mu \mathrm{M}$. Additionally, this effect increased with ongoing exposure time (Hassenklöver and Bickmeyer, 2006). We, therefore, may strongly underestimate the efficacy of TBP.

In sea water samples from the German Bight up to $6 \mathrm{ng} \mathrm{\textrm {L } ^ { - 1 }}$ TBP (equivalent to $0.02 \mathrm{nM}$ ) are reported while the highest level of all identified bromophenols was $74 \mathrm{ng} \mathrm{L}^{-1}$ (Reineke et al., 2006). Higher levels of bromophenols are found in marine sediments and macroalgae: In estuarine sediments from the Rhone river up to $3.7 \mathrm{mg} \mathrm{kg}^{-1} \mathrm{TBP}$ were found and in the marine macroalgae Ulva lactua up to $1.6 \mathrm{mg} \mathrm{kg}^{-1} \mathrm{TBP}$ have been detected (Howe et al., 2005). Regarding the environmental levels of $\mathrm{Cu}^{2+}$, concentrations range from 0.2 to $2.6 \mu \mathrm{g} \mathrm{L}^{-1}$ dissolved $\mathrm{Cu}^{2+}$ (equivalent to 3 to $41 \mathrm{nM}$ ) in the North Sea. Indeed, at point sources up to $600 \mu \mathrm{g} \mathrm{L}^{-1}$ dissolved $\mathrm{Cu}^{2+}$ (equivalent to $9 \mu \mathrm{M}$ ) can be found (Bryan and Langston, 1992). The effective concentrations of $\mathrm{Cu}^{2+}$ and TBP tested in this study are, therefore, higher than relevant aqueous concentrations in the marine environment, except for $\mathrm{Cu}^{2+}$ at point sources. Regarding TBP, exposure and uptake by sea urchins need to be further investigated in regard to high TBP contamination of sediments in their habitats and the high TBP levels of macroalgae which may serve as food source as already proposed by Agatsuma et al. (2008). The effective concentrations of $\mathrm{Cu}^{2+}$ are above the European safe level of $41 \mathrm{nM} \mathrm{Cu}^{2+}$ in marine waters (European Copper Institute, 2008). Indeed, it should be considered that during measuring the $\mathrm{Ca}^{2+}$ signal at fertilization eggs were not exposed to the tested chemicals to avoid interference of the MRP inhibitor with the test substances. Effective concentrations of $\mathrm{Cu}^{2+}$ and TBP on $\mathrm{Ca}^{2+}$ signalling at fertilization in $P$. miliaris are, therefore, likely to be lower than the tested concentrations of $6.3 \mu \mathrm{M} \mathrm{Cu}^{2+}$ and $100 \mu \mathrm{M}$ TBP, respectively.

In contrast to the effects on the $\mathrm{Ca}^{2+}$ wave at fertilization, we were not able to detect induction of $\mathrm{Ca}^{2+}$ signals by exposure of unfertilized eggs to $\mathrm{Cu}^{2+}$ and TBP. Indeed, the low dye loading of the eggs in comparison to eggs microinjected with indicator dyes in conjunction with the large size of the eggs limits detectability and resolution of intracellular $\mathrm{Ca}^{2+}$ changes in these cell types.

We demonstrate that $\mathrm{Cu}^{2+}$ and TBP affect calcium signalling at fertilization in sea urchin eggs. This may contribute to the reduced fertilization success of $P$. miliaris exposed to $\mathrm{Cu}^{2+}$ and TBP, respectively. Disturbance of $\mathrm{Ca}^{2+}$ channels and homeostasis by heavy metals have previously been suggested to affect acrosome reaction and motility of invertebrate sperm (Earnshaw et al., 1986, Au et al., 2001). Since sperm motility is directly correlated with fertilization success (Au et al., 2002) further studies are needed to investigate the effects of $\mathrm{Cu}^{2+}$ and TBP on sperm motility of sea urchins. Next to fertilization, early development is regulated by $\mathrm{Ca}^{2+}$ (Whitaker, 2006) and may be prone to disturbance of calcium homeostasis by TBP and $\mathrm{Cu}^{2+}$. Increased $\mathrm{Ca}^{2+}$ levels can trigger the release of hormones from secretory granules but they can also initiate signalling cascades by activation of kinases which may rapidly affect embryonic development. Sustained increase in intracellular $\mathrm{Ca}^{2+}$ may further activate $\mathrm{Ca}^{2+}$-dependent degradative enzymes, compromise mitochondrial function and cytoskeletal organization, and ultimately result in cell death.

In the present study, we successfully visualized the calcium wave at fertilization in eggs of sea urchins without using methods risking injury of the cell membrane: In eggs of $P$. miliaris incubated with Fura-2 AM and the MRP inhibitor MK571 we observed clear $\mathrm{Ca}^{2+}$ signals at fertilization. Still, it has to be considered that transport inhibitors may reduce fertilization-evoked $\mathrm{Ca}^{2+}$-signals in sea urchin eggs (Davis et al., 2008). In previous studies, Fura-2 was microinjected into eggs of the sea urchin Lytechinus pictus to measure the $\mathrm{Ca}^{2+}$ rise at fertilization (Poenie et al., 1985; Swann and Whitaker, 1986). Simple incubation of eggs with Fura-2 AM has already been performed to investigate $\mathrm{Ca}^{2+}$ signals in mouse eggs (Hyslop et al., 2001 ). However, we could not observe $\mathrm{Ca}^{2+}$ signals in sea urchin eggs incubated with Fura-2 AM only. Similarly, Stricker et al. (1992) mentions that in eggs of the sea urchin Lytechinus pictus incubated with acetoxymethylesters of the calcium indicator dyes fluo-3 and calcium green no $\mathrm{Ca}^{2+}$ wave at fertilization could be detected.

MK571 is a specific blocker for MRP transporters and its application has been suggested to facilitate loading of animals cells (Manzini and Schild, 2003; Bickmeyer et al., 2008) as well as diatoms (Scherer et al. 2008) with calcium indicator dyes. Eggs and embryos of the sea urchin Strongylocentrotus purpuratus are known to express efflux transport activity (Hamdoun et al., 2004). Hamdoun et al. (2004) have shown that the efflux activity is relatively low in unfertilized eggs but is dramatically upregulated within 25 min postfertilization possibly by translocation of transporters in vesicles to the plasma membrane (Hamdoun et al., 2004). In sea stars, immunocytochemistry revealed that MRP-like proteins are localized throughout the cytoplasm in oocytes and translocated to the periphery during oocyte maturation (Roepke et al., 2006). After fertilization, eggs of the sea urchin Lytechinus pictus microinjected with the calcium indicator fluo-3 show higher fluorescence intensities in the cortex than in the centre of the cell. (Stricker et al., 1992). Possibly, in the absence of MK571 Fura-2 is extruded from the cytoplasmic spaces just underneath the plasma membrane by MRP transporters. Changes in intracellular $\mathrm{Ca}^{2+}$ which may primarily occur in these cellular regions may, therefore, not be detected when MRP transporters are active.

As demonstrated in the present study, decreasing fluorescence intensities of Fura- 2 at 340 and $380 \mathrm{~nm}$ excitation induced by cell movements may result in an increasing ratio of F340/F380. This rise in the ratio of F340/F380 may be misinterpreted as an increase in intracellular $\mathrm{Ca}^{2+}$ concentration. Indeed, Fura-2 changes its fluorescence spectrum upon binding of $\mathrm{Ca}^{2+}$ ions in opposite ways: at $340 \mathrm{~nm}$ the intensity increases whereas at $380 \mathrm{~nm}$ it decreases (Grynkiewicz et al., 1985). The observed decrease in the fluorescence intensity of Fura-2 is due to gross movement of the eggs: Movement of cells is known as major artefact in imaging techniques using fluorescent dyes (Tsien et al., 1985; Silver et al., 1992). In the present study, attacking sperm caused slight movement of the eggs during in vitro fertilization. Moreover, eggs changed their shape upon fusion with sperm which is also known from other microscopic studies (Schatten, 1981; Stricker et al., 1992).

\section{Acknowledgements}

This study was financed by the Alfred Wegener Institute for Polar and Marine Research within the Helmholtz Association. It is part of a $\mathrm{PhD}$ study conducted at the Jacobs University Bremen. The authors would like to thank B. Hussel and the staff of the FS Mya for collecting and B. Krüss and A. Röw for maintenance of the sea urchins. We sincerely acknowledge the support of the staff at the Biologische Station Helgoland during the experiments. We would like to thank three anonymous reviewers for their helpful comments on the manuscript.

\section{References}

Agatsuma, Y., Endo, H., Taniguchi, K., 2008. Inhibitory effect of 2,4-dibromophenol and 2,4,6-tribromophenol on larval survival and metamorphosis of the sea urchin Strongylocentrotus nudus. Fish. Sci. 74, 837-841.

Au, D.W.T., Reunov, A.A., Wu, R.S.S., 2001. Reproductive impairment of sea urchin upon chronic exposure to cadmium. Part II: Effects on sperm development. Environ. Pollut. 111, 11-20.

Au, D.W.T., Chiang, M.W.L., Tang, J.Y.M., Yuen, B.B.H., Wang, Y.L., Wu, R.S.S., 2002. Impairment of sea urchin sperm quality by UV-B radiation: Predicting fertilization success from sperm motility. Mar. Pollut. Bull. 44, 583-589. 
Barhoumi, R., Awooda, I., Mouneimne, Y., Safe, S., Burghardt, R.C., 2006. Effects of benzo-a-pyrene on oxytocin-induced $\mathrm{Ca}^{2+}$ oscillations in myometrial cells. Toxicol. Lett. 165, 133-141.

Bickmeyer, U., Lüders, A.K., Saborowski, R., 2008. Multidrug resistance transporter in the midgut gland and the brain of crustaceans. Comp. Biochem. Physiol. A 151, S2-S3.

Bielmyer, G.K., Brix, K.V., Capo, T.R., Grosell, M., 2005. The effects of metals on embryolarval and adult life stages of the sea urchin, Diadema antillarum. Aquat. Toxicol. 74, 254-263.

Boyle, J.L., Lindsay, R.C., Stuiber, D.A., 1992. Bromophenol distribution in salmon and selected seafoods of fresh-water and saltwater origin. J. Food Sci. 57, 918-922.

Bryan, G.W., Langston, W.J., 1992. Bioavailability, accumulation and effects of heavy metals in sediments with special reference to United Kingdom estuaries - a review. Environ. Pollut. 76, 89-131.

Büsselberg, D., Evans, M.L., Rahmann, H., Carpenter, D.O., 1990. Lead inhibits the voltage-activated calcium current of aplysia neurons. Toxicology Letters 51, 51-57.

Caldwell, G.S., Olive, P.J.W., Bentley, M.G., 2002. Inhibition of embryonic development and fertilization in broadcast spawning marine invertebrates by water soluble diatom extracts and the diatom toxin 2-trans,4-trans decadienal. Aquat. Toxicol. 60, 123-137.

Carafoli, E., 2002. Calcium signaling: a tale for all seasons. Proc. Natl. Acad. Sci. U. S. A. 99, 1115-1122.

Carroll, M., Levasseur, M., Wood, C., Whitaker, M., Jones, K.T., McDougall, A., 2003. Exploring the mechanism of action of the sperm-triggered calcium-wave pacemaker in ascidian zygotes. J. Cell Sci. 116, 4997-5004.

Churchill, G.C., Okada, Y., Thomas, J.M., Genazzani, A.A., Patel, S., Galione, A., 2002. NAADP mobilizes $\mathrm{Ca}^{2+}$ from reserve granules, lysosome-related organelles, in sea urchin eggs. Cell 111, 703-708.

Covian-Nares, F., Martİnez-Cadena, G., Lopez-Godinez, J., Voronina, E., Wessel, G.M., Garcia-Soto, J., 2004. A Rho-signaling pathway mediates cortical granule translocation in the sea urchin oocyte. Mech. Dev. 121 (3), 225-235.

Davila, D.R., Davis, D.P., Campbell, K., Cambier, J.C., Zigmond, L.A., Burchiel, S.W., 1995. Role of alterations in $\mathrm{Ca}^{2+}$-associated signaling pathways in the immunotoxicity of polycyclic aromatic hydrocarbons. J. Toxicol. Environ. Health 45, 101-126.

Davis, L.C., Morgan, A.J., Ruas, M., Wong, J.L., Graeff, R.M., Poustka, A.J., Lee, H.C., Wessel, G.M., Parrington, J., Galione, A., 2008. $\mathrm{Ca}^{2+}$ signalling occurs via second messenger release from intraorganelle synthesis sites. Curr. Biol. 18, 1612-1618.

Earnshaw, M.J., Wilson, S., Akberali, H., Butler, R.D., 1986. The action of heavy metals on the gametes of the marine mussel, Mytilus edulis (L.) - III. The effect of applied copper and zinc on sperm motility in relation to ultrastructural damage and intracellular metal localisation. Mar. Environ. Res. 20, 261-278.

European Copper Institute and Instituto Superiore di Sanità 2008. The copper voluntary risk assessment. A pioneering industry/member state partnership approach to the duty of care. Scandinavian copper development association. 23.03.2009 http://www. scda.com/files/copper_voluntary_risk_assesment_july_1_2008.pdf.

Fernández, N., Beiras, R., 2001. Combined toxicity of dissolved mercury with copper, lead and cadmium on embryogenesis and early larval growth of the Paracentrotus lividus sea urchin. Ecotoxicology 10, 263-271.

Fielman, K.T., Woodin, S.A., Lincoln, D.E., 2001. Polychaete indicator species as a source of natural halogenated organic compounds in marine sediments. Environ. Toxicol. Chem. 20, 738-747.

Galione, A., 1994. Cyclic ADP-ribose, the ADP-ribosyl cyclase pathway and calcium signalling. Mol. Cell. Endocrinol. 98, 125-131.

Genazzani, A.A., Wilson, H.L., Galione, A., 1999. Psammechinus miliaris egg homogenate as a model to investigate $\mathrm{Ca}^{2+}$-release mechanisms. J. Mar. Biol. Assoc. UK 79, 323-326.

Girard, J.-P., Ferrua, C., Pesando, D., 1997. Effects of tributyltin on $\mathrm{Ca}^{2+}$ homeostasis and mechanisms controlling cell cycling in sea urchin eggs. Aquat. Toxicol. 38 225-239.

Gopalakrishnan, S., Thilagam, H., Vivek Raja, P., 2008. Comparison of heavy metal toxicity in life stages (spermiotoxicity, egg toxicity, embryotoxicity and larval toxicity) of Hydroides elegans. Chemosphere 71, 515-528.

Grynkiewicz, G., Poenie, M., Tsien, R.Y., 1985. A new generation of $\mathrm{Ca}^{2+}$ indicators with greatly improved fluorescence properties. J. Biol. Chem. 260, 3440-3450.

Hamdoun, A.M., Cherr, G.N., Roepke, T.A., Epel, D., 2004. Activation of multidrug efflux transporter activity at fertilization in sea urchin embryos (Strongylocentrotus purpuratus). Dev. Biol. 276, 452-462.

Hassenklöver, T., Bickmeyer, U., 2006. The marine secondary metabolites 2,4-dibromophenol and 2,4,6-tribromophenol differentially modulate voltage dependent ion currents in neuroendocrine (PC12) cells. Aquat. Toxicol. 79, 384-390.

Hassenklöver, T., Predehl, S., Pilli, J., Ledwolorz, J., Assmann, M., Bickmeyer, U., 2006. Bromophenols, both present in marine organisms and in industrial flame retardants, disturb cellular $\mathrm{Ca}^{2+}$ signaling in neuroendocrine cells (PC12). Aquat. Toxicol. 76, 37-45.

His, E., Heyvang, I., Geffard, O., de Montaudouin, X., 1999. A comparison between oyster (Crassostrea gigas) and sea urchin (Paracentrotus lividus) larval bioassays for toxicological studies. Water Res. 33, 1706-1718.

Holland, I.B., Blight, M.A., 1999. ABC-ATPases, adaptable energy generators fuelling transmembrane movement of a variety of molecules organisms from bacteria to humans. J. Mol. Biol. 293, 381-399.

Howe, P.D., Dobson, S., Malcom, H.M., 2005. 2,4,6-tribromophenol and other simple brominated phenols. Concise International Chemical Assessment Document 66. International Programme on Chemical Safety (IPCS). World Health Organization (WHO).

Hyslop, L.A., Carroll, M., Nixon, V.L., McDougall, A., Jones, K.T., 2001. Simultaneous measurement of intracellular nitric oxide and free calcium levels in chordate eggs demonstrates that nitric oxide has no role at fertilization. Dev. Biol. 234, 216-230.
Jaffe, L.A., Giusti, A.F., Carroll, D.J., Foltz, K.R., 2001. $\mathrm{Ca}^{2+}$ signalling during fertilization of echinoderm eggs. Sem. Cell Dev. Biol. 12, 45-51.

King, C.K., Riddle, M.J., 2001. Effects of metal contaminants on the development of the common Antarctic sea urchin Sterechinus neumayeri and comparisons of sensitivity with tropical and temperate echinoids. Mar. Ecol. Prog. Ser. 215, 143-154.

Kiyomoto, M., Kikuchi, A., Unuma, T., Yokota, Y., 2006. Effects of ethynylestradiol and bisphenol A on the development of sea urchin embryos and juveniles. Mar. Biol 149, 57-63.

Kobayashi, N., 1980. Comparative sensitivity of various developmental stages of sea urchins to some chemicals. Mar. Biol. 58, 163-171.

Kobayashi, N., 1990. Marine pollution bioassay by sea urchin eggs, an attempt to enhance sensitivity. Publ. Seto Mar. Biol. Lab. 34, 225-237.

Latimer, J.S., Zheng, J., 2003. The sources, transport and fate of PAHs in the marine environment. In: Douben, P.E.T. (Ed.), PAHs: An Ecotoxicological Perspective. John Wiley and Sons Incorporated, New York, NY, pp. 9-33.

Law, R.J., Dawes, V.J., Woodhead, R.J., Matthiessen, P., 1997. Polycyclic aromatic hydrocarbons $(\mathrm{PAH})$ in seawater around England and Wales. Mar. Pollut. Bull. 34, 306-322.

Leslie, E.M., Deeley, R.G., Cole, S.P.C., 2001. Toxicological relevance of the multidrug resistance protein 1, MRP1 (ABCC1) and related transporters. Toxicology 167, 3-23.

Lüdeking, A., Van Noorden, C.J.F., Koehler, A., 2005. Identification and characterisation of a multidrug resistance-related protein mRNA in the blue mussel Mytilus edulis. Mar. Environ. Prog. Ser. 286, 167-175.

Manzini, I., Schild, D., 2003. Multidrug resistance transporters in the olfactory receptor neurons of Xenopus laevis tadpoles. J. Physiol. 546, 375-385.

Nicotera, P., Orrenius, S., 1998. The role of calcium in apoptosis. Cell Calcium 23, 173-180.

Nicotera, P., Bellomo, G., Orrenius, S., 1992. Calcium-mediated mechanisms in chemically-induced cell-death. Annu. Rev. Pharmacol. Toxicol. 32, 449-470.

Nielsen, H.D., Brown, M.T., Brownlee, C., 2003. Cellular responses of developing Fucus serratus embryos exposed to elevated concentrations of $\mathrm{Cu}^{2+}$. Plant Cell Environ. $26,1737-1747$

Pesando, D., Girard, J.-P., Durand-Clément, M., Payan, P., Puiseux-Dao, S., 1991. Effect of maitotoxin on sea urchin egg fertilization and on $\mathrm{Ca}^{2+}$ permeabilities of eggs and intracellular stores. Biol. Cell 72, 269-273.

Pesando, D., Lemée, R., Ferrua, C., Amade, P., Girard, J.-P., 1996. Effects of caulerpenyne, the major toxin from Caulerpa taxifolia on mechanisms related to sea urchin egg cleavage. Aquat. Toxicol. 35, 139-155.

Pessah, I.N., Beltzner, C., Burchiel, S.W., Sridhar, G., Penning, T., Feng, W., 2001. A bioactive metabolite of benzo[a]pyrene, benzo[a]pyrene-7,8-dione, selectively alters microsomal $\mathrm{Ca}^{2+}$ transport and ryanodine receptor function. Mol. Pharmacol 59, 506-513.

Pillai, M.C., Vines, C.A., Wikramanayake, A.H., Cherr, G.N., 2003. Polycyclic aromatic hydrocarbons disrupt axial development in sea urchin embryos through a [beta]catenin dependent pathway. Toxicology 186, 93-108.

Poenie, M., Alderton, J., Tsien, R.Y., Steinhardt, R.A., 1985. Changes of free calcium levels with stages of the cell-division cycle. Nature 315, 147-149.

Reineke, N., Biselli, S., Franke, S., Heinzel, N., Hühnerfuss, H., Iznaguen, H., Kammann, U. Theobald, N., Vobach, M., Wosniok, W., 2006. Brominated indoles and phenols in marine sediment and water extracts from the North and Baltic Seas - concentrations and effects. Arch. Environ. Contam. Toxicol. 51, 186-196.

Roepke, T.A., Snyder, M.J., Cherr, G.N., 2005. Estradiol and endocrine disrupting compounds adversely affect development of sea urchin embryos at environmentally relevant concentrations. Aquat. Toxicol. 71, 155-173.

Roepke, T.A., Hamdoun, A.M., Cherr, G.N., 2006. Increase in multidrug transport activity is associated with oocyte maturation in sea stars. Dev. Growth Differ. 48, 559-573.

Santella, L., Lim, D., Moccia, F., 2004. Calcium and fertilization: the beginning of life Trends Biochem. Sci. 29, 400-408.

Schatten, G., 1981. The movements and fusion of the pronuclei at fertilization of the sea urchin Lytechinus variegatus - time-lapse video microscopy. J. Morphol. 167, 231-247.

Scherer, C., Wiltshire, K., Bickmeyer, U., 2008. Inhibition of multidrug resistance transporters in the diatom Thalassiosira rotula facilitates dye staining. Plant Physiol Biochem. 46, 100-103.

Schmidt, T., Patton, C., Epel, D., 1982. Is there a role for the $\mathrm{Ca}^{2+}$ influx during fertilization of the sea urchin egg? Dev. Biol. 90, 284-290.

Silver, R.A., Whitaker, M., Bolsover, S.R., 1992. Intracellular ion imaging using fluorescent dyes - artifacts and limits to resolution. Pflugers Arch. 420, 595-602.

Steevens, J.A., Slattery, M., Schlenk, D., Aryl, A., Benson, W.H., 1999. Effects of ultraviolet$\mathrm{B}$ light and polyaromatic hydrocarbon exposure on sea urchin development and bacterial bioluminescence. Mar. Environ. Res. 48, 439-457.

Steinhardt, R., Zucker, R., Schatten, G., 1977. Intracellular calcium release at fertilization in the sea urchin egg. Dev. Biol. 58, 185-196.

Stohs, S.J., Bagchi, D., 1995. Oxidative mechanisms in the toxicity of metal ions. Free Radic. Biol. Med. 18, 321-336.

Stricker, S.A., 1999. Comparative biology of calcium signaling during fertilization and egg activation in animals. Dev. Biol. 211, 157-176.

Stricker, S.A., Centonze, V.E., Paddock, S.W., Schatten, G., 1992. Confocal microscopy of fertilization-induced calcium dynamics in sea urchin eggs. Dev. Biol. 149, 370-380.

Suzuki, N., Kambegawa, A., Hattori, A., 2003. Bisphenol A influences the plasma calcium level and inhibits calcitonin secretion in goldfish. Zool. Sci. 20, 745-748.

Swann, K., Whitaker, M., 1986. The part played by inositol trisphosphate and calcium in the propagation of the fertilization wave in sea urchin eggs. J. Cell Biol. 103, 2333-2342.

Tsien, R.Y., Rink, T.J., Poenie, M., 1985. Measurement of cytosolic free $\mathrm{Ca}^{2+}$ in individual small cells using fluorescence microscopy with dual excitation wavelengths. Cell Calcium 6, 145-157. 
U.S. EPA, 1993. Sea urchin, Arbacia punctulata, fertilization test, method 1008.0, Shortterm methods for estimating the chronic toxicity of effluents and receiving waters to marine and estuarine organisms, 2nd ed. US Environmental Protection Agency, Cincinnati, OH, pp. 300-340. report EPA/600/4-91/003, July 1994.

Walter, P., Allemand, D., Derenzis, G., Payan, P., 1989. Mediating effect of calcium in $\mathrm{HgCl}_{2}$ cytotoxicity in sea urchin egg - role of mitochondria in $\mathrm{Ca}^{2+}$-mediated celldeath. Biochim. Biophys. Acta 1012, 219-226.

Whitaker, M., 2006. Calcium at fertilization and in early development. Physiol. Rev. 86, $25-88$.
Whitfield, F.B., Helidoniotis, F., Shaw, K.J., Svoronos, D., 1999. Distribution of bromophenols in species of marine algae from eastern Australia. J. Agric. Food Chem. 47, 2367-2373.

Wozniak, A.L., Bulayeva, N.N., Watson, C.S., 2005. Xenoestrogens at picomolar to nanomolar concentrations trigger membrane estrogen receptor-alpha-mediated $\mathrm{Ca}^{2+}$ fluxes and prolactin release in GH3/B6 pituitary tumor cells. Environ. Health Perspect. 113, 431-439.

Zorita, I., Ortiz-Zarragoitia, M., Soto, M., Cajaraville, M.P., 2006. Biomarkers in mussels from a copper site gradient (Visnes, Norway): An integrated biochemical, histochemical and histological study. Aquat. Toxicol. 78, S109-S116. 